\title{
PROFILE OF SENIOR HIGH SCHOOL METACOGNITIVE ABILITY IN SOLVING PROBLEMS OF ABSTRACT ON PHYSICS MATERIAL
}

\author{
Helda Yanti ${ }^{1}$, I Wayan Distrik ${ }^{2}$, and Isra Khasyyatillah ${ }^{3}$ \\ ${ }^{1,2}$ physics education department, Program Pascasarjana, Universitas Lampung, Indonesia. \\ ${ }^{3}$ Science Education Department, Universiti Kebangsaan Malaysia, Malaysia. \\ e-mail: ${ }^{1}$ heldayanti41@yahoo.co.id, ${ }^{2}$ wayandistrik8@ gmail.com, ${ }^{3}$ p91948@ siswa.ukm.edu,my
}

Received 27 July 2017; Accepted 11 October 2017; Published 28 October 2017

\begin{abstract}
This study aims to determine the ability of students' metacognition in solving abstract problems in physical material. The study involved students who took through the test. Metacognition ability data obtained through written test consisting of questions metacognitive knowledge and metacognition skills. Data analysis is done descriptively. The result of the research shows that declarative knowledge dominates students metacognition knowledge, that is students can recognize the difficult problem and able to interpret in other forms but less able to recognize method used and how to finish, while students' metacognition skills are more dominant in planning and monitoring fields. Prediction and evaluation skills are still relatively low. Overall, metacognition ability of students included in the low category.
\end{abstract}

C2017 Physics Education, FTK UIN Raden Intan Lampung

Keywords: metacognition, physics material, profile of student

\section{INTRODUCTION}

Static electricity is very abstract, complex, and involves very complicated mathematics (Mur et al., 2004), so problems in the material are trying to solve (Demİrcİ \& Çİrkİnoğlu, 2004). The study of the static electrical material is the primary goal of developing students' thinking ability on static electrical material thoroughly both on macroscopic, microscopic and symbolic scales. Students can be said understanding static electricity material when students can transfer and connect between macroscopic, microscopic and symbolic phenomenon in learning, and also when they can solve problems given. To support it, it is required good metacognition skills in each student. Because the ability of metacognition has positive influences toward problemsolving abilities (Distrik, 2013).
A child with a metacognitive strategy will soon realize that he does not understand the problem and try to find a way out. According to Eggen \& Kauchak (1996) in (Corebima, 2007), the development of metacognitive skills in students is a valuable educational goal because the skill can help them become a self-regulated learner. The self-regulated learner is responsible for self-learning progress and adaptation of learning strategies to achieve task demands.

Metacognition refers to ways of raising awareness of thinking and learning process which is undertaken. This awareness will be realized if one can initiate thinking by planning, monitoring and evaluating the results and cognitive activity (Woolfolk, 1998). Another opinion states that metacognition is an awareness of cognitive activity. In this case, metacognition is related to how one is aware of the thought process (Lee, M. \& Baylor, 2006). A study that tests 
metacognitive in education states that metacognitive processes can enhance learning toward perfection, for example, learners become acquainted with themselves as self-regulating beings who can achieve conscious and deliberate goals, Kluwe in (Hacker, 2000). Metacognition was divided into metacognition knowledge, metacognition skills, and metacognition or metacognition beliefs (Desoete, Roeyers, \& Buysse, 2001). However, Lucangeli, Tressoldi, \& Cendron (1998) incorporate metacognition into metacognition knowledge. Furthermore, Brown in (Fazal, 2011) describes metacognition knowledge into declarative, procedural, and conditional knowledge while cognitive regulation consists of planning, monitoring, and evaluating. In another opinion (Desoete et al., 2001) divides the executive control or metacognition skills into four parts consisting of predicting, planning, monitoring, and evaluating.

According to (Schneider \& Artelt, 2010), declarative knowledge is primarily knowledge of the world or commonsense knowledge, instrumental in the study of artificial intelligence (Schneider \& Artelt, 2010). In other words, declarative knowledge or awareness of oneself as the learner and what factors may affect the learner's performance (Schraw, Crippen, \& Hartley, 2006). Procedural knowledge is demonstrated by knowledge of strategy and knowledge management that ultimately helps in doing something. Conditional knowledge involves when and why to use specific strategies, allowing students to allocate their resources. Such an assessment of the application makes the strategy to be more efficient (Reynolds, 1992).

Students who can manage their cognitive activities well, allowing them to handle tasks and solve problems well
(Flavell, 1979). Differences in the ability of physics allow for different metacognition processes which students do when troubleshooting. (Lee, M., and Baylor, 2006) states that "metacognition as the ability to understand and monitor one's thoughts and the assumptions and implications of one's activities." In line with the above statement, (Saregar, Diani, \& Kholid, 2017; Saregar, Latifah, \& Sari, 2016) also suggests educators use alternative learning models that may impact on students' high-order thinking ability.

The writer considers that it is necessary to know the profile of students' metacognition in solving the problem. The metacognition profile in this research is the description of what is about student's cognition which involves declarative, conditional, procedural, prediction, and awareness and thinking in planning their thinking process, monitoring the thinking process and evaluating the process and the result of his thinking when solving the problem on the abstract material of static electricity physics. The purpose of this study was to reveal the metacognition profile of high school students in solving physics problems in the abstract material.

\section{METHOD}

This research uses direct test design. This research was conducted on the even semester of the academic year 2016/2017 in Gajah Mada High School Bandar Lampung. Purposive sampling technique chose the sample. This study involved 35 students from XII IPA class.

Data collection methods in this study using paper and pencil test. Metacognition capability tests tailored to static electricity materials comprise metacognition and metacognition skills. Metacognition ability is divided into 
declarative ability, limited ability, and procedural capability while for metacognition skills consists of prediction skills, planning skills, evaluating and monitoring skills. The number of test items consists of 7 questions about static electricity. An essay test developed by the researchers themselves. The scoring is given to each problem with the highest score is 4 , and the lowest is 1 , based on scoring rules that have been prepared by researchers. The test of metacognitive ability has been tested its validity and reliability on the students of XII IPA class. Based on the test results, it is declared valid and reliable. The test is given after the treatment of the class.

Data analysis was done descriptively. Descriptive analysis is done through transcripts and grouped in low, medium, and high categories. The data were analyzed descriptively which analyzed each item to see the form of representation used in solving the problem.

\section{RESULT AND DISCUSSION}

Preliminary research results that have been done in SMA Gajah Mada Bandar Lampung, the data are obtained in Table 1,

Table 1. Average form of student representation in solving physics problems

\begin{tabular}{lccccccc}
\hline \multirow{2}{*}{ Aspect } & \multicolumn{7}{c}{ Solving Problems Indicator } \\
\cline { 2 - 8 } & D & C & P & pr & Pl & ev & M \\
\hline Av & 1,4 & 1 & 1 & 1,86 & 2,14 & 1,68 & 2,14 \\
\hline T H & 2 & 1 & 1 & 2 & 4 & 2 & \\
\hline TL & 1 & 1 & 1 & 1 & 1 & 1 & 1 \\
\hline \% & 35 & 25 & 25 & 46,43 & 53,6 & 42,14 & 53,57
\end{tabular}

Noted:

$\mathrm{D}=$ Declarative, $\mathrm{C}=$ conditional

$\mathrm{P}=$ procedural, $\quad \mathrm{Pr}=$ prediction

$\mathrm{Pl}=$ planning,$\quad \mathrm{Ev}=$ evaluating

$\mathrm{M}=$ monitoring, $\mathrm{Av}=$ average

$\mathrm{TH}=$ The highest, $\mathrm{TL}=$ The lowest
Declarative knowledge problem by using meaning difference scale of (Semantics) to measure whether the problem-solving task can be done easily or difficulty at a level (unity sequence). Based on the result of research in Table 1, only a small part of student can do declarative matter correctly which means the student cannot explain electrical principles force by point charge correctly from the problem which is considered easy. A student must be prepared to question 'Do I know this?' To assess their knowledge (Paris \& Winograd, 1990). This is in line with students answer to a matter of limited knowledge where the student is not sufficient to assess convenience given problem; the student cannot mention the reason why applying a particular strategy in solving the electrical force problem. In procedural knowledge problem, students are assigned to describe stages of problemsolving on the most perceived problem. Based on the above observations, all stages of problem-solving given by students is wrong; it means that students cannot arrange the problem-solving steps related to electric force; whereas knowledge of various strategies can enable individuals to solve problems more efficiently and automatically (Pressley M., Borkowski J. G, 1987).

In predicting skills material, based on Table 1 of 35 students, students who believe can answer the questions correctly but in fact, the answers given are wrong, or the students believe that they cannot do the problem correctly but it turns out the correct answer given.There are 30 students, and 5 of them even stated very confidently that they could answer it but they give wrong answers. It means that students are not able to make predictions about their ability to solve problems. On the matter 
of student planning skills, writing numbers 1-3 to match the correctness of steps in solving the problem. Based on Table 1, the average student can only answer one correct answer even some students give all wrong answers. This means that students cannot select the appropriate strategy to work on the problem. On the matter of monitoring skills, students chose an option by their ability to solve the problem but based on Table 1; students cannot monitor every step used. In the evaluation problem, there are four options, and the student responds by giving a score to each option. 1 for the critical question (first order), 2 for the second order, 3 for the third order and 4 for the question which is the last question.

The average student only answers a correct sequence of answers even some students answer all unordered answers. It shows that students' skills in predicting, planning, monitoring and evaluating are so low instead many different solutions that people can produce when solving a problem will be determined mainly by how well a person predicts, plans, monitors and evaluates his thinking processes and thinking outcomes when making plans solution to the problem. They are in line with those disclosed (Polya, 1973) that problem-solving abilities are in the idea of drafting a plan. Thus, this phrase indicates that better one plotting his thinking process when creating a problem-solving plan, better resulting solution.

Metacognition ability is needed in improving conceptual understanding especially in abstract physics material (Distrik, I W., Jatmiko, B., \&Supardi, 2013). This statement is in line with the results of the study (Panaoura \& Philippou, 2004) showing that students who are skilled in knowing and managing their cognition (judging their metabolism) and realizing their ability will demonstrate more strategic thinking skills in solving problems than those who are unaware of how their cognitive systems work. The results (McLoughlin, C. \& Hollingworth, 2003) show that effective problem solving can be obtained by allowing students to expose metacognitive strategies when solving problems. It is clear that there is a correlation between metacognition and problem-solving. Metacognition ability can be obtained through learning as stated by (Distrik, I W., Jatmiko, B., \&Supardi, 2013) that metacognitive ability can be obtained through learning with analogy and reflection strategy.

\section{CONCLUSION}

Based on the description above it can be concluded that students' metacognition ability in solving physics problems in the abstract material included in the low category, both regarding knowledge and metacognitive skills. Students are less able to recognize easy and difficult questions. Students also experience similar difficulties in giving reasons, making procedures, predicting, planning, monitoring, and evaluating it. It indicates that students rarely do metacognitivebased learning. Researchers suggest conducting follow-up research on learning strategies that can improve students' metacognition ability in solving abstract physics problems.

\section{REFERENCES}

Corebima, A. D. (2007). Metakognisi: Suatu Ringkasan Kajian, Makalah disajikan dalam Diklat Guru Mata Pelajaran Biologi di Yogyakarta. Demİrcİ, N., \& Çİrkİnoğlu, A. (2004). Determining Students'

Preconceptions/Misconceptions in 
Electricity and Magnetism. Journal of Turkish Science Education, 1(2), 51-54.

Desoete, A., Roeyers, H., \& Buysse, A. (2001). Metacognition and Mathematical Problem Solving in Grade 3. Journal of Learning Disabilities, 34(5), 435-449. https://doi.org/10.1177/0022219401 03400505

Distrik, I W., Jatmiko, B., \&Supardi, Z. A. . (2013). Strategi Pengajaran Metakognitif melalui Analogi dan Refleksi untuk Meningkatkan Kemampuan Metakognitif dan Pemahaman Konsep Fisika. In Prosiding Seminar Nasional FMIPA. ISBN: 978-6-0217146-6-9.

Distrik, I. W. (2013). Pemahaman Konsep dan Keterampilan Pemecahan Masalah Mahasiswa Calon Guru Pendidikan Fisika pada Materi Listrik Magnet. In Prosiding seminar Nasional. SBN:978-6027508-55-2. (pp. 233-238).

Fazal, R. ur. (2011). Assessment of Science Teachers Metacognitive Awareness and its impact on the Performance of Students. Dissertation of Doctor of Departement of Secondary Teacher Education Faculty of Education Allama Iqbal Open University Islamabad.

Flavell, J. H. (1979). Metacognition and Cognitive Monitoring: A New Area of Cognitive-Developmental Inquiry. American Psychologist, 34(10), 906-911. https://doi.org/10.1037/0003066X.34.10.906

Hacker, D. J. (2000). Metacognition: Definitions and Empirical Foundations.

Lee, M., and Baylor, A. L. (2006). Designing Metacognitive Maps for
Web-Based Learning. Educational Technology \& Society, 9(1), 344348.

Lee, M. \& Baylor, A. L. (2006). Designing Metacognitive Maps for Web-Based Learning. USA: Florida State University.

McLoughlin, C. \& Hollingworth, R. (2003). Exploring a Hidden Dimension of Online Quality: Metacognitive Skill Development. In 16th ODLAA Biennial Forum Conference Proceedings.

Mur, J., Zaragoza, de Luna, M., Letosa, J., Samplón, M., \& Artal, S. J. (2004). Teaching Electricity and Magnetism in Electrical Engineering Curriculum: Applied Methods and Trend. In International Conference on Engineering Education (pp. 111).

Panaoura, A., \& Philippou, G. (2004). The Measurement of Young Pupils' Metacognitive Ability in Mathematics: the Case of SelfRepresentation and Self-Evaluation, 1-10.

Paris, S. G., \& Winograd, P. (1990). Promoting Metacognition and Motivation of Exceptional Children. Remedial and Special Education, 11(6), 7-15. https://doi.org/10.1177/0741932590 01100604

Polya, G. (1973). How to Solve It. NewJersey: Princeton University Press.

Pressley M., Borkowski J. G, and. S. W. (1987). Cognitive Strategies: Good Strategy Users Coordinate Metacognition and Knowledge. Annals of Child Development.

Reynolds, R. E. (1992). Selective Attention and Prose Learning: Theoretical and Empirical Research. Educational Psychology Review, 4, 
345-391.

Saregar, A., Diani, R., \& Kholid, R. (2017). Efektivitas Penerapan Model Pembelajaran ATI (Aptitude Treatment Interaction) Dan Model Pembelajaran TAI (Team Assisted Individualy): Dampak Terhadap Hasil Belajar Fisika Siswa. Jurnal Pendidikan Fisika Dan Keilmuan, 3(1), 28-35.

Saregar, A., Latifah, S., \& Sari, M. (2016). Efektivitas Model Pembelajaran CUPs: Dampak terhadap Kemampuan Berpikir Tingkat Tinggi Peserta Didik Madrasah Aliyah Mathla'ul Anwar Gisting Lampung. Jurnal Ilmiah Pendidikan Fisika Al-Biruni, 5(2), 233-243.

https://doi.org/10.24042/jpifalbiruni. v5i2.123

Schneider, W., \& Artelt, C. (2010). Metacognition and Mathematics education. ZDM Mathematics Education, 42(2), 149.

Schraw, G., Crippen, K. J., \& Hartley, K. (2006). Promoting Self-Regulation in Science Education: Metacognition as Part of a Broader Perspective on Learning. Research in Science Education, 36, 111-139. https://doi.org/10.1007/s11165-0053917-8

Woolfolk, A. (1998). Educational Psychology (Seventh Ed). Boston: Allyn and Bacon. 